This is a pre-copyedited, author-produced version of an article accepted for publication in Acta Sociologica. The version of record Aart-Jan Riekhoff, Satu Ojala \& Pasi Pyöriä (2021). Career stability in turbulent times: A cross-cohort study of mid-careers in Finland is available online at: https://journals.sagepub.com/doi/full/10.1177/0001699320983422. 


\title{
Career stability in turbulent times: A cross-cohort study of mid-careers in Finland
}

\author{
Aart-Jan Riekhoff, \\ Position: Senior researcher, Finnish Centre for Pensions \\ Postal address: 00065 Eläketurvakeskus, Finland \\ Telephone: +358294112361 \\ Email: arie.riekhoff@etk.fi
}

\begin{abstract}
Satu Ojala
Position: University lecturer, Faculty of Social Sciences, Tampere University

Postal address: Faculty of Social Sciences, 33014 Tampere University, Finland

Phone number: +358 503186176

Email address: satu.ojala@tuni.fi
\end{abstract}

\section{Pasi Pyöriä}

Position: Senior lecturer, Faculty of Social Sciences, Tampere University

Postal address: Faculty of Social Sciences, 33014 Tampere University, Finland

Phone number: +358 503186188

Email address: pasi.pyoria@tuni.fi

\section{Author biographical notes:}

Aart-Jan Riekhoff obtained a $\mathrm{PhD}$ in social policy from the University of Tampere in 2018. Currently he works as a senior researcher at the Finnish Centre for Pensions. His research focuses on employment, retirement, and social inequalities across the life course.

Satu Ojala is a university lecturer in social policy at Tampere University. She is specialised in the studies of working conditions and employment careers over time, applying representative time series and register-based data.

Pasi Pyöriä is a senior lecturer in sociology at Tampere University who focuses on working life and labour market studies. His research interests include job quality and working conditions, precarious work, work careers, telework, and knowledge work. 


\title{
Career stability in turbulent times: A cross-cohort study of mid-careers in Finland
}

\begin{abstract}
In this article, we investigate whether the mid-career stability of Finnish men and women has changed for the birth cohorts 1958 to 1972, and, if so, what the driving forces are behind such changes. We analyse career stability during a 15-year period following the age of 30 using 'career turbulence' indicators. To identify the impact of cyclical and structural changes in the labour market, we analyse the association between initial employment status and sector with subsequent career stability. We distinguish between sectors that are exposed to a greater or lesser extent to global competition, those that are characterised by goods production or service provision, and those that are part of the market or non-market sector. In a series of OLS regression and regression decomposition analyses, we also control for the impact of education, regional unemployment, and family-formation processes. The results show little change in mid-career stability across cohorts. Stability increased somewhat when only including transitions between employment and nonemployment, whereas slight destabilisation was observed when accounting for changes between jobs. The findings indicate that the small changes in stability across cohorts were mostly driven by structural changes in the labour market, albeit with different mechanisms for men and women.
\end{abstract}

\section{Keywords}

career sequences, career stability, cross-cohort changes, linked employer-employee data, regression decomposition, Finland

Word count: 7990 (main text, references and endnotes) 


\section{Introduction}

It is often argued that the standard employment relationship - full-time and life-time employment with a single employer - is giving way to contingent employment. Increasing numbers of wage and salary earners are running the risk of discontinuous and fragmented careers (Potter, 2015). They change jobs and occupations or move in and out of paid work more often than before. This means growing volatility, heterogeneity, and unpredictability in career trajectories. The usual suspects behind the career destabilisation hypothesis are forces that restructure the labour market: global competition, technological development, deindustrialisation, business cycle fluctuations, and labour market deregulation (Fenton and Dermott, 2006; Jarvis and Song, 2017; Struffolino and Raitano, 2020).

However, empirical evidence for the career destabilisation hypothesis is lacking or at best inconclusive (Biemann et al., 2011; Hollister, 2011; Jarvis and Song, 2017; Schellenberg et al., 2016; Van Winkle and Fasang, 2017). Little is still known about the mechanisms behind the destabilisation hypothesis: whereas careers may destabilise for some, there might be simultaneous increases in career stability for others (Riekhoff, 2018; Struffolino and Raitano, 2020). Changes in career stability may occur because of shifts in activity between different parts of the economy or because certain parts of the economy change in ways that lead to greater or lesser stability.

As the jury is still out on whether career destabilisation is taking place, for whom, and if so, what the mechanisms are behind it, this study aims to revisit these questions using Finland as a case in point. We investigate changes in mid-career stability across the 1958-1972 cohorts and how an individual's characteristics at age 30 are associated with career stability during a 15-year follow-up. We focus on the impact of employment status at 30, divided into being unemployed, being a student or being employed in four broad types of sectors that reflect a relative vulnerability to the macroprocesses of globalisation, deindustrialisation, marketisation, and economic downturn. Additionally, we control for individual education levels and the family formation process as well as 
regional economic differences. With the use of regression decomposition, we analyse whether changes in career stability between cohorts can be attributed to a changing composition of the study population or because their careers became inherently more or less stable due to observable or unobservable factors.

Finland makes an interesting case for studying changes in career stability, as it represents rapid modernisation and flexible adaptation to economic and technological change (Pyöriä, 2006). In Europe, Finland was a latecomer in shifting from an agrarian to an industrialised society. When the oldest cohorts of our study entered the labour market in the late 1980s, the economy boomed, and the Finnish welfare state had expanded to one of the most encompassing in Europe. In the early 1990s the country slipped into a banking crisis and recession. Social expenditure was cut severely, while the labour market was somewhat liberalised. The recovery that followed was equally dramatic - due in large part to the country’s newly emergent technology sector. Again in 2008-2009, Finland faced the global financial crisis, abruptly ending a long period of strong economic growth, reflecting once more a small open economy’s vulnerability to international shocks.

Finland also offers an important illustration of the mechanisms behind career destabilisation from a gender perspective. Whereas female labour market participation has been almost on a par with men's participation rates since the 1980s, occupational segregation is higher than in many European countries and continues to lead to different labour market outcomes for men and women (European Commission, 2009; Grönlund et al., 2017; Lahtinen et al., 2020). Moreover, when compared to the situation for men, younger Finnish women's careers are more often interrupted for longer periods of time due to childbearing and care leaves, leading to considerably different outcomes in further careers (Kuitto et al., 2019). A low-rate cash-for-childcare system until the child is three years old serves as an incentive for mothers to interrupt their careers for longer time, especially among those in a weaker labour market position before motherhood. 
Previous studies mainly concentrate on stability in early careers and school-to-work transitions (e.g. Brzinsky-Fay and Solga, 2016; Scherer, 2005) or late careers (e.g. Riekhoff, 2018; Fasang, 2012), whereas much less attention has been paid to mid-careers. The years between ages 30 and 45 are a crucial time for family formation (Aisenbrey et al., 2009; Aisenbrey and Fasang, 2017) and mark a period when workers become attached to the labour market while seeking promotional opportunities or new career alternatives (Manzoni et al., 2014; Schellenberg et al., 2016; Virtanen et al., 2011). Moreover, events in mid-careers are likely to have a lasting impact on later working life, retirement, and well-being in older age.

\section{Theoretical background}

\section{How do careers destabilise? Concepts and measures}

Brückner and Mayer (2005) draw the distinction between the de-standardisation and differentiation of life courses. Whereas the term de-standardisation refers to increasing heterogeneity of life courses between individuals, differentiation refers to an increasing number of distinct stages across the individual lifetime. Differentiation is a process of increasing complexity in the life course, leading to greater instability and unpredictability (Riekhoff, 2018). During the last decade, lifecourse research has increasingly used longitudinal measures of life-course complexity, as they offer a way to move away from single labour market transitions and to focus on studying holistic trajectories (Pelletier et al., 2020).

We equate destabilisation of careers with the differentiation of employment life courses. The complexity of careers can depend on the transitions between labour market statuses (e.g. employment, unemployment and inactivity) and changes between jobs. Although the term ‘destabilisation’ usually has negative connotations, Biemann et al. (2011) argued that the complexity or stability of careers provides no information about the quality and direction of (the 
lack of) transitions (p. 1659). Career stability can provide predictability and security, but not if one is stuck in a 'bad job’ (Kalleberg, 2011). Career instability can indicate job insecurity as well as both downward and upward mobility in the labour market. In our study, we concentrate on destabilisation as the deviance of the norm of continuous employment with a single employer.

Studies on changes in career stability across time or cohorts have found little or no change, although results differ depending on the country, period, and age brackets that are under scrutiny as well as operationalisation of the career complexity measures (Biemann et al., 2011; Struffolino and Raitano, 2020; Van Winkle and Fasang, 2017; Widmer and Ritschard, 2009). Still, little is known about the forces behind changes in career stability. First, when studying changes across time, it is often unclear whether they result from variation between cohorts or periods. For example, careers can become more stable because across cohorts due to educational expansion reducing the risks of career breaks and leading to better matches in the labour market (Jarvis and Song, 2017, p. 569). However, during certain periods, industrial restructuring or labour market deregulation can increase the risk of unemployment and have a destabilising effect. Biemann et al. (2011, p. 1642) suggest that cohorts and periods can have counteracting effects.

Second, and related to cohort and period effects, it is often unclear how career stability changes. Career stability is usually averaged over the entire population. It can change when the size of certain groups with particularly high or low levels of career changes. For example, when the higher educated experience lower career complexity, educational expansion leads to a decline in career instability in the total population. It is also possible that career complexity changes inherently, either for the whole population or for specific groups. For example, when unemployment increases, the careers of especially those groups that are more vulnerable to unemployment might destabilise. 


\section{What destabilises careers?}

Careers are often expected to destabilise due to the macroprocesses of globalisation, deindustrialisation, and economic shocks. Economic globalisation has increased pressure on governments to deregulate the labour market (Buchholz et al., 2008; Rubery et al., 2016). This leads to employment relations being terminated more easily, thus forcing workers to seek out new jobs more frequently. Technological automation and deindustrialisation (a shift from manufacturing to services) has halted the predominance of (especially men’s) life-long careers in industrial production. It has given rise to both low-level service-sector jobs that are often temporary or peripheral by nature (Kalleberg, 2011). Finally, the deregulation of product and labour markets has increased workers' volatility in the face of economic fluctuations, making the impact of economic shocks potentially deeper and the scarring effects of career disruptions more sustained (Buchholz et al., 2008; López-Andreu and Rubery, 2018).

These are not forces of nature and do not lead to destabilisation of careers everywhere. There are differences by country due to variation in institutions (Mayer, 2005). Möhring (2016) identified various employment life-course regimes in Europe ranging from lowly standardised, gendered, and segmented career trajectories in Greece and Spain to flexibly standardised careers in the Nordic countries that combine continuous careers in full-time employment with frequent changes between labour market statuses. Labour market institutions play an important role. Van Winkle and Fasang (2017) found little change in career complexity across time, but substantial variation between countries, which can be largely attributed to differences in unemployment benefit generosity and employment protection legislation. This also implies that when labour market institutions are reformed, this may lead to changes in career stability. Struffolino and Raitano (2020) found increases in career complexity following labour market deregulation in Italy.

Whereas national labour market institutions can provide protection against external pressures, some workers are arguably more vulnerable to career destabilisation than others. This is because not 
all parts of the economy are equally exposed to globalisation, deindustrialisation, and economic shocks. For Germany, Biemann et al. (2011) tested whether between the 1950s and 2000s careers destabilised at a faster rate in economic sectors that were more exposed to globalisation and experience faster growth. They found no relation between the sector's exposure to globalisation and career destabilisation but found that careers were more complex in both particularly low- and highgrowth sectors. Differentiating between sectors of tradeable goods and services on the one hand and non-tradeable services on the other, Eliasson and Hansson (2016) pointed out that in Sweden, workers in sectors more open to globalisation were more vulnerable to unemployment. A sector that is typically shielded from career destabilisation is the public sector (Biemann et al., 2012).

Economic recession can have contradictory effects on career stability. On the one hand, it can increase the risk of career interruptions due to unemployment and stimulate more frequent changes in jobs to avoid unemployment. Rokkanen and Uusitalo (2010) found that in Finland job stability decreased during the recession years of the early 1990s. On the other hand, average job tenure can increase during a recession, especially due to the loss of short-tenured jobs (Bachmann and Felder, 2018). If fewer jobs are available and job switching seems riskier, workers will be more inclined to stay with their current employer.

\section{Gender differences in career destabilisation}

Career destabilisation might follow different patterns among men and women. In most countries, women have on average higher early- and mid-career complexity than men (Biemann et al., 2011; Van Winkle and Fasang, 2017; Widmer and Ritschard, 2009). This is to a large extent due to family formation processes: women are more likely to have longer career breaks due to childbearing and caring while men stay in the labour market to provide for their families (Kuitto et al., 2019). These breaks might affect women’s chances of job mobility in their career long after parental leave (Aisenbrey et al., 2009; Evertsson et al., 2016). 
There are mixed reports about whether women's occupational careers are destabilising at a faster rate compared to men's, although it should also be noted most studies include cohorts that are somewhat older than those analysed in the present article. Biemann et al. (2011) and Van Winkle and Fasang (2017) report no substantial gender differences in career destabilisation. Widmer and Ritschard (2009) found a greater destabilisation of occupational trajectories among women in Switzerland, arguing that 'women took on their shoulders most of the flexibilization of the economy that has happened since the seventies' (p. 37). Women entered the labour market, but mainly in the more volatile low-level service jobs. Struffolino and Raitano (2020) concur that labour market deregulation in Italy in the eighties had stronger negative effects on the career stability of women compared to that of men.

There are also reasons to expect that women's careers destabilise at a slower rate compared to men's careers. First, the demise of life-long jobs in manufacturing particularly affects men's careers. Second, women in Finland traditionally work in public-sector jobs, which are more shielded against economic shocks and offer higher levels of job stability. Third, educational expansion has taken place among women in particular, possibly leading to more opportunities for stable employment patterns (Biemann et al., 2011). Fourth, and related to the previous point, bettereducated and more work-oriented women have fewer children and at a later age, while having shorter career disruptions following marriage and children (Aisenbrey and Fasang, 2017; Härkönen et al., 2016; Manzoni et al., 2014).

\section{Data and methods}

\section{Data and study population}

The Finnish Longitudinal Employer-Employee Data (FLEED) is a large register-based dataset produced annually by Statistics Finland from 1988 to 2016. The full version of the dataset contains all 15-70-year-olds permanently residing in Finland. It combines data from various administrative 
registers on employment, education, taxation, and business, and it includes identifiers on the individual, establishment, and enterprise levels, making it a very rich source of information for the purpose of this study.

Our study population consists of individuals born in the years 1958-1972. We follow these individuals from the year in which they turned 30 until the year they turned 44 . We start this followup period at the age of 30, as we are mainly interested in those who can be expected to be attached to the labour market to a reasonable extent (Virtanen et al., 2011). Other studies confirmed that occupational positions generally start to stabilise around the age of 30 (Härkönen and Bihagen, 2011, p. 454; Lahtinen et al., 2020, p. 308). Stawarz (2018) concurs that once a person is employed, there are only modest changes in intragenerational social mobility over time. We excluded those who are outside of paid employed throughout the whole follow-up period (about 3\% of the total population). This leaves us with a total study population of 1,020,274 individuals. Summary statistics for the study population are presented in Table 1.

\section{<Table 1 about here>}

\section{Dependent variables}

To operationalise a measure of career stability as our dependent variable, we apply Elzinga’s method to calculate sequence turbulence (Elzinga, 2010). ${ }^{1}$ This indicator measures the complexity of sequences based on the number of transitions and the length of sub-sequences (Pelletier et al., 2020). In the context of this study, it can be considered more adequate than simply counting the number of transitions, as stability or predictability of careers does not only depend on the number of times that statuses change, but also on how long each spell of those statuses lasts and whether one returns to a previous state or not. If a person remains in the same initial state throughout the followup, the turbulence indicator equals 1. 
We differentiate between two sequence types in order to create two possible measures of career destabilisation. With the first type, destabilisation indicates an increase in the unpredictability of transitions in and out of employment (which we henceforth will refer to as 'status turbulence'), while the second type of destabilisation additionally indicates an increase in unpredictability due to transitions between jobs ('status-job turbulence'). Exploring the differences between these two types might provide an indication of whether changes in career stability are due to spells of nonemployment or changes between employers.

The data has information on each individual's labour market status at the end of each of the 15 follow-up years. This information is combined and used to build two types of sequences of 15 annual statuses. The first sequence type consists of main statuses only and includes employed, unemployed, pensioner, student, and other. The 'other' category includes those who are inactive or performing military or community service. It should be noted that women and men who take parental leave generally continue to stay employed with the same employer during that period, hence no change in their status is observable in the data. Their status changes only if the parent's contract ends (about a fifth of women at age 30 are temporarily employed) or if one does not return to the same employer after the one-year entitled parental leave or the additional two-year optional cash-for-childcare absence. In case an individual exits the data during the follow-up, e.g. due to moving abroad or death, their status changes to 'missing'. However, by the age of 44 the share of missing values is only 2.6 per cent and we find no substantial changes between cohorts. The turbulence indicator of sequences with only labour market statuses has a minimum value of 1 and a maximum value of 13.45 .

The second type of sequence consists of the same categories as the first type, but additionally differentiates the employment category by the number of jobs within the sequence. Based on the establishment identifier in the data, it is possible to follow whether someone changes employer. For each individual, the first job is marked as 'Job 1'. If the establishment code changes, the status will 
change to 'Job 2', etc. Due to the 15 years of follow-up, the maximum number of jobs (and statuses within this sequence type) is 15 , meaning that the maximum value of the status-job turbulence indicator also reaches up to 15 . Due to the greater number of possible states in the status-job turbulence indicator, it has higher values on average (see also Table 1).

One limitation of the data is that establishment identifiers in the public sector are often missing and have been subject to changes in certain years. For this reason, all public-sector establishments were attributed a single identifier. In other words, the data do not record changes of jobs within the public sector. This limitation might lead to an underestimation of status-job turbulence, especially among women. In our data, women work on average 5.4 years in the public sector, compared to 2.8 years for men. Also, changes in status-job turbulence across cohorts might be affected. Publicsector employment decreased between the 1958 and 1972 cohorts, from an average of 5.9 to 5.3 years among women and from 3.4 to 2.3 years among men.

Sequences including spells of public sector employment are kept in the data, as removing them would exclude a large section of the working population, especially women. There are several reasons to assume that overall and actual career stability is not affected drastically by this decision. Jobs in the public sector are generally more stable than in the private sector and involuntary job changes less common. Moreover, job changes in the Finnish public sector are likely to occur for the same large employer, which is in most cases the municipality. Job changes between public and private sectors are still recorded in the data. In the interpretation of our results we focus on career stability in the private sector. Controls for sector of employment in the multivariate analysis allow to correct some of the distorting effects of missing employer information in the public sector. 


\section{Independent variables}

To analyse the impact of employment status at age 30 on mid-career stability, detailed information on labour market statuses and industries of employment is used. For those employed, we regrouped industries into four broad categories based on three dimensions: production vs services, tradeable vs non-tradeable, and market vs non-market. The new categories are: 1) tradeable production (incl. agriculture, mining, and manufacturing); 2) tradeable services (e.g. accommodation, transportation, administrative and support services, information and communication, and finance and insurance); 3) non-tradeable market sector (e.g. wholesale and retail trade, construction, and real estate activities); and 4) non-tradeable non-market sector (e.g. electricity and gas, public administration, education, and health and social work).

According to the logic of this division, we expect the tradeable sectors (both goods and services) to be more affected by globalisation. The distinction between goods and services (both tradeable and non-tradeable) allows the identification of the relation between deindustrialisation and career stability. The market and non-market sectors may differ in the protection they offer against structural change and economic shocks. Moreover, the dummy for employment in the non-tradable non-market sector on subsequent career stability controls for the lacking information on job changes in the public sector. This seems an adequate control for careers in the public sector, because those employed in this sector at age 30 worked there during on average 12 years of the follow-up.

Admittedly, the boundaries between the sector dimensions are not always clear. Definitions are open to theoretical and empirical debate, whereas differences exist per country and across time even in the presence of standardised NACE coding. Particularly the distinction between tradeable and non-tradeable can be operationalised in several ways. We based our classification of tradeable and non-tradeable sectors on Piton (2018), who empirically tested with Eurostat data which services and goods are actually more or less traded in the European Union. Construction, for example, is tradeable in theory but in practice its activities concentrate within countries or even regions. Our 
classifications broadly correspond to those from studies on Sweden and France, which use measures of geographical concentration to identify tradeable industries (Eliasson and Hansson, 2016; Frocrain and Giraud, 2017). The distinction between the market and non-market sectors may be ambiguous due to (quasi-)privatisations (such as in electricity and gas) and parallelly operating private and public services (such as in health care). The distinctions were based on how these divisions broadly existed in 1988 and how some of these services can still be considered public goods even if they have been subject to privatisation and marketisation.

Three additional categories were created for those not employed at age 30: unemployed, student and employed in unknown sector. It should be noted that those careers are automatically more unstable compared to those of the employed, because they make at least one transition into employment (remember that those who were never employed during the follow-up period are excluded from the study). It is of interest to see whether those entered employment from the position of a student had a better starting position to more stable careers than those who exit from unemployment.

Figure 1 indicates of how these employment statuses developed across cohorts. The rate of unemployment among 30-year olds largely reflects changes in the economic cycle. Employment rates were at an all-time high in Finland in the late 1980s but were followed by searing unemployment rates in the early 1990s because of the deep economic recession the country experienced. Employment in the tradeable goods and non-tradeable market sectors reached bottom levels with the 1963 cohort, but subsequently recovered. The non-market sector saw a but steady decline in employment, while employment in tradeable services expanded across the cohorts.

\section{$<$ Figure 1 about here $>$}

We further control for the economic cyclical effects and the impact of regional labour market conditions by averaging the unemployment rate of the individual's region of residence for each of 
the 15 years during the follow-up. Regional units are based on the 21 provinces of the 2016 Finnish regional division. Moving between regions during the follow-up is accounted for in the regional unemployment indicator. A control for level of education was operationalised by calculating a continuous variable for years in education, based on the required number of years spent in education, to reach the attainment level that was recorded at age 30.

Controls are included for marital status at age 30 with three categories: single, married or in a registered partnership, and divorced or widowed. To analyse the effects of family-formation processes, we used the information at age 30 and age 44 for the presence and number of underaged children in the household. We divided family-formation processes into four broad types: 1) having no children at age 30 and none at 44;2) having no children at 30 but having children at 44 ; 3 ) having children at 30 but not more at 44; and 4) having children at 30 and having more at 44 . We separated all our models by gender, as we expected that the mechanisms behind career stability are different for men and women.

\section{Methods and analytical strategy}

The data are analysed in three stages. First, descriptive graphs are generated showing the changes in the average career turbulence indicators for both men and women. Second, OLS regression is performed with cohort-fixed effects on both turbulence indicators and for men and women separately. Running 'empty models’ with only dummies for birth year allows the identification of how much variance can be explained by changes between cohorts only. The full models show the relation of the other factors with career stability.

In the third step, regression decomposition analysis, as first developed by Kitagawa (1955) and later popularized by Blinder (1973) and Oaxaca (1973), is used to estimate the impact on the changing career stability of, on one hand, changes in endowments (the 'explained' or 'composition' 
part) and, on the other, changes in coefficients (the 'unexplained' or 'association' part) (Jann, 2008). The endowment part of Kitagawa-Blinder-Oaxaca (KBO) decomposition analysis provides an indication of changes in career stability that are due to changes in characteristics in the population, for example educational expansion or increases in employment in more turbulent sectors. The coefficients part identifies the changes in returns to certain characteristics. In other words, it is possible that average career stability does not change due to changes in the size of certain population groups, but because careers become inherently less or more stable within certain groups. Moreover, the constant in the coefficients part of KBO can hint at whether non-observed factors moderate career stability.

In this last part, three broader groups of cohorts are compared: those born in 1958-1962 are compared with the 1963-1967 and 1968-1972 cohorts. This is done in order to focus on the broader developments across cohorts and to avoid the risk of having a single reference year for which data might have deviations in coding or other outliers. Moreover, these three cohort groups broadly cover some of the cyclical trends observed in Finland. The oldest cohort experienced low but rising unemployment in their early thirties, the middle cohort experienced high unemployment at 30 followed by recovery, and the youngest cohort benefited from a steady economic recovery in their early thirties but experienced the 2008-2009 crisis in the later years.

\section{Findings}

Figure 1 shows the average status turbulence (Panel a) and status-job turbulence (Panel b) by year of birth and gender. When looking at career stability as measured by status turbulence (Panel a), one can observe a slightly declining trend in turbulence. Among women, this downward trend was preceded by a small increase between the 1958 and 1962 cohorts. Despite this, the overall changes are not large. There is, however, a considerable and consistent gap between men's and women's 
career stability: women’s careers are more unstable throughout all cohorts. When including changes between employers (Panel b), careers are almost entirely stable across cohorts with a very slight upward trend. There is no substantial gap between men and women. This result indicates that men's career instability is to a larger extent affected by changes in jobs, whereas women's career instability is rather the result of changes between employment and non-employment.

\section{$<$ Figure 2 about here $>$}

\section{Regression analysis}

Table 2 presents the results for regression analysis predicting the two types of career stability for men and women separately. Fixed effects for cohorts were included, but in order to save space the coefficients of the cohort dummies are not reported in this table (see bivariate associations in Table A1 in the Appendix) The R-squared values for the 'empty models' - i.e. models with cohort dummies - only indicate that differences by cohort alone account for less than half of one percent in all of the models. In other words, the differences in career stability between cohorts were small. Adding the other predictors increases the R-squared value substantially in all models.

The strongest predictor of career stability in all models is being employed or not (i.e. being unemployed, student or otherwise inactive) at age 30. Compared to the reference group of working in the tradeable goods sector, those in the tradeable services sector experienced a somewhat higher level of status turbulence (Models 1-2). In terms of status-job turbulence, men and women in the tradeable services sector had substantially more unstable careers (Models 3-4). Those in the nontradeable market sector had more unstable careers compared to workers in the tradeable goods sector, but this effect was stronger for men (Models 1 and 3) than for women (Model 2 and 4). Careers that started in the non-market sector at the age of 30 were the most stable. 
Among the controls, higher regional unemployment during the follow-up period is related to higher career instability, except for status-job turbulence among men. The results show that more years in education are related to lower career instability, again apart from status-job turbulence among men. Being married is related to lower levels of career instability, while being single and especially widowed or divorced is associated with higher levels of career instability among both men and women. Childless women have the lowest levels of career instability, whereas childless men have the highest levels. Especially having children between the ages of 30 and 44 leads to greater career instability among women, whereas among men it is related to greater career stability.

\section{<Table 2 about here>}

\section{Regression decomposition}

Although the prior results indicated only small changes in career stability across cohorts, we continue with the decomposition analysis of changes in the turbulence indicators between the 19581962 and 1963-1967 cohorts. Detailed results of the KBO analysis of the differences between cohorts are presented in Table A2 in the Appendix. The same results are visually represented in Figures 3 and 4, only as changes in turbulence between the older and younger cohorts. Each bar in the figures represent the contribution of the endowments (E) and coefficients (C) of each covariate to the overall change between the two cohort groups. Positive contributions (i.e. associated with increases in turbulence) are displayed in blue and the negative contributions (i.e. associated with decreases in turbulence) are in orange.

Panel a and $b$ in Figure 3 show that the average status turbulence decreased 0.191 points for men (from 3.090 to 2.899) and 0.076 points for women (from 3.908 to 3.832). Changes in composition of employment statuses are associated with a large increase in turbulence among both men and women. In other words, if nothing else had changed between the cohorts, status turbulence 
would have increased with 0.289 points for men and 0.338 points for women between the two cohorts due to changes in the composition of employment statuses. Inspection of the detailed contributions of each sector (not reported here) indicate that this was particularly due to the growth of those unemployed at age 30. Decreases in regional unemployment had a counteracting impact on status turbulence, especially among women. The large size of the constant indicates that other unobserved factors were associated with careers being more stable than they could have been.

Panels c and d in Figure 3 show increases in status-job turbulence among both men (from 5.315 to 5.474) and women (from 5.444 to 5.636). The results corroborate that being unemployed at age 30 contributes to the large effect of endowments on turbulence, but among women a reduction in public-sector employment also played a role. Inspection of the detailed contributions of sectors showed that among men there is a substantial stabilising impact of the coefficient of the nontradeable market sector. It is possible that in that sector, job changes were especially reduced due to the economic downturn. The decline in regional unemployment rates contributed to a substantial increase in turbulence among men, but to a decrease among women. The contributions of other factors to inter-cohort change were relatively small. The contribution of the constant is much smaller than in the case of status turbulence.

\section{$<$ Figure 3 about here $>$}

Panels a and b in Figure 4 show the decomposition of changes in status turbulence (from 3.090 to 2.798 for men and from 3.908 to 3.645 for women) between the youngest and oldest cohort groups. Among men there was almost no impact of changes in employment status endowments, whereas among women this impact was rather substantial. Among the latter, careers grew more unstable due to further increases in not being employed and to some extent decreases in publicsector employment. Decreases in regional unemployment levels and increases in education years contributed to lower career instability, especially among women. More than half of the decrease in 
status turbulence is due to coefficients, especially changes in the constant, i.e. factors outside our models.

Figure $4 c$ and $d$ show the results of the same analysis with status-job turbulence as the dependent variable. For men, status-job turbulence increased from 5.315 to 5.466 and for women from 5.444 to 5.597. Increases in status-job turbulence were particularly due to changes in endowments. Inspection of the detailed contributions of employment status categories (not reported) shows that men's careers destabilised especially due to increases in unemployment at age 30, but also because of decreases in regional unemployment in the long run. Status-job turbulence of those in the non-tradeable market sector at age 30 decreased, contributing to career stabilisation through coefficients. For women, the decline in the non-tradable non-market sector contributed to destabilisation, whereas declining regional unemployment rates and rising education levels acted somewhat as a counterforce. The effects of coefficients on changes between the oldest and youngest cohorts were considerably smaller, with an almost negligible effect of the constant.

\section{$<$ Figure 4 about here $>$}

\section{Discussion}

In this article, we investigated whether Finnish mid-careers destabilised between the cohorts born in 1958 and 1972, as well as the potential driving forces between changes in career stability. Overall, we found that careers were relatively stable across cohorts. When looking at sequences of main labour market statuses only (status turbulence), careers became somewhat more stable, whereas when including changes between jobs (status-job turbulence), careers destabilised somewhat. This relative stability is in line with most previous studies with similar research designs and survey data, including both single and multiple countries (Biemann et al., 2011; Hollister, 2011; Van Winkle and Fasang, 2017). 
One potential explanation behind this relative stability is the structuring and buffering influence of institutions on labour market behaviour. Earlier studies have pointed out that career stability strongly varies across countries but little over time, pointing to family and labour market policies as stabilising factors (Möhring, 2016; Van Winkle and Fasang, 2017). Finland did not experience any structural labour market deregulation during the period under investigation, like for example Italy (Struffolino and Raitano, 2020). While we do not have a direct measure for the effects of these policies as 'automatic career stabilisers', the KBO analysis indicates that during the worst years of the economic recession in Finland in the early 1990s, the potentially large increases in turbulence due to non-employment and unemployment were outbalanced by the 'unexplained' constant. This suggests that although the change in labour market conditions would have destabilised careers, something that is not explained by our variables prevented that from happening.

Through the KBO analysis we were able to observe that, although especially changes in the characteristics of the population at age 30 were relatively large between cohorts, they did not necessarily lead to large changes in career stability. Careers generally also did not become inherently more turbulent. Focusing on employment statuses, we found no potential effects of globalisation through the tradeable sectors, even though the share of employment in tradeable services steadily increased during the timeframe of our study. Career stability in the non-tradeable sector for men showed more fluctuation over time. This effect might be due to the influence of the construction sector, which is 'cyclically sensitive' (Eurofound, 2017): in better economic times, the large demand for construction workers allows them to change jobs more easily. There was also no evidence of destabilisation due to the deindustrialisation that took place during this period. However, between the oldest and youngest cohorts of women, a large part of the increase in statusjob turbulence was due to the long-term decline in employment in the non-tradeable non-market (i.e. public) sector. 
There were considerable differences in the patterns of changes in career stability between men and women. Status turbulence was consistently higher among women than among men. In line with findings from a broad range of other studies (Aisenbrey and Fasang, 2017; Kuitto et al., 2019; Widmer and Ritschard, 2009), this finding is likely to be related to women's career breaks due to childbearing and childrearing. This is the case even in the context of this study, where Finnish parents, or at least those in permanent employment, have the right to remain employed after childbirth and where being on a parental leave itself should not add to higher turbulence with our data. Still, the higher status turbulence is likely due to mothers' longer time-outs from employment directly or indirectly following childbirth. Evertsson et al. (2016), showed that young women’s work interruptions can have lasting impact on the likelihood of being employed years later. In contrast, among men having children was associated with greater career stability. Moreover, our study suggests that changes in family-formation processes across cohorts, particularly the trend of having children at a later age, have a greater destabilising effect on women’s careers than on men’s.

The differences in average status-job turbulence between men and women are negligible. This nonetheless indicates that men's status-job turbulence is to a much larger degree determined by changes in jobs, while women's status-job turbulence is to a larger degree the result of transitions in and out of employment. There are some indications that greater job instability might actually benefit men. First, we found that higher educated men have higher job turbulence and that educational expansion is associated with destabilisation. Second, we found that lower unemployment increases men’s job turbulence. Among women, the directions of these relations were the opposite. It is possible that better skills and lower unemployment provide men with upward job mobility, whereas they provide women with stable careers.

This brings us to some of the main limitations of this study. As Pelletier et al. (2020) have recently shown, different measures for life-course complexity might yield somewhat different results. Moreover, using turbulence indicators carries the risk of obfuscating the quality of labour 
market transitions. Conventional panel or survival models can be used to estimate the risks of specific transitions between statuses and jobs. Yet, we chose to adopt a holistic approach in order to span an entire life-course phase. Analysing both turbulence including statuses only as well as turbulence including job changes allowed us to differentiate between these two dimensions of career stability. Unlike other complexity measures, the turbulence indicator accounts for the duration of spells spent in each state. Recent studies have incorporated concerns for detecting upward or downward trends in sequence data, for example by including dimensions of precarity (Ritschard et al., 2018) and vulnerability (Bühlmann, 2018). Studies on upward and downward occupational mobility can shed more light on the possible positive and negative effects of career destabilisation (Aisenbrey and Fasang, 2017; Jarvis and Song, 2017; Stawarz, 2018).

We continue to live in turbulent times in which labour markets and the nature of work seem to be changing fast. Nevertheless, our study shows that amid all this turbulence, mid-careers are relatively stable. It is possible that Finnish mid-careers are particularly stable, even in times of economic shocks, because at age 30 many people have had the chance to settle into a steady job and have built up rights for employment protection and earnings-related social security. It is not unlikely that changes in early-career stability have been more drastic. Slow change, however, also means that disparities in career stability tend to persist. Women, the lower-educated, those in lessdeveloped regions, and workers in certain sectors are especially at risk of unstable employment careers, possibly with detrimental consequences for the further life course. 


\section{Acknowledgements}

Satu Ojala and Pasi Pyöriä received funding from the Finnish Work Environment Fund and the Academy of Finland. 


\section{Notes}

1. For each sequence $x$, turbulence $T$ can be calculated as:

$$
T(x)=\log _{2}\left(\phi(x) \frac{s_{t, \max }^{2}(x)+1}{s_{t}^{2}(x)+1}\right)
$$

where $s_{t}^{2}$ stands for the variance of the state-duration and $s_{t, \max }^{2}$ is the maximum value that this variance can take based on the total length of the sequence. This maximum is calculated by:

$$
s_{t, \max }^{2}=(n-1)(1-\bar{t})^{2}
$$

with $\bar{t}$ representing the mean consecutive time spent in each of the distinct states and $n$ is the length of the distinct state sequence (Gabadinho et al., 2010). 


\section{References}

Aisenbrey S, Evertsson M and Grunow D (2009) Is there a career penalty for mothers' time out? A comparison of Germany, Sweden and the United States. Social Forces 88(2): 573-605.

Aisenbrey S and Fasang A (2017) The interplay of work and family trajectories over the life course: Germany and the United States in comparison. American Journal of Sociology 122(5): 14481484.

Bachmann R and Felder R (2018) Job stability in Europe over the cycle. International Labour Review 157(3): 481-518.

Biemann T, Fasang A and Grunow D (2011) Do economic globalization and industry growth destabilize careers? An analysis of career complexity and career patterns over time. Organization Studies 32(12): 1639-1663.

Biemann T, Zacher H and Feldman D (2012) Career patterns: A twenty-year panel study. Journal of Vocational Behavior 81(2): 159-170.

Blinder AS (1973) Wage discrimination: Reduced form and structural estimates. Journal of Human Resources 8(4): 436-455.

Brückner H and Mayer KU (2005) De-standardization of the life course: What it might mean? And if it means anything, whether it actually took place? Advances in Life Course Research 9: 2753.

Brzinsky-Fay C and Solga H (2016) Compressed, postponed, or disadvantaged? School-to-worktransition patterns and early occupational attainment in West Germany. Research in Social Stratification and Mobility 46(A): 21-36.

Buchholz S, Hofäcker D, Mills M, Blossfeld HP, Kurz K and Hofmeister H (2008) Life courses in the globalization process: The development of social inequalities in modern societies. European Sociological Review 25(1): 53-71. 
Bühlmann F (2018) Trajectories of vulnerability: A sequence-analytical approach. In: Tillmann R, Voorpostel M and Farago P (eds) Social Dynamics in Swiss Society. Empirical Studies Based on the Swiss Household Panel. Cham: Springer, pp. 129-143.

Eliasson K and Hansson P (2016) Are workers more vulnerable in tradable industries? Review of World Economics 152(2): 283-320.

Elzinga CH (2010) Complexity of categorical time series. Sociological Methods \& Research 38(3): 463-481.

Eurofound (2017) Occupational change and wage inequality: European Jobs Monitor 2017. Luxembourg: Publications Office of the European Union.

European Commission (2009) Gender segregation in the labour market. Root causes, implications and policy responses in the EU. Luxembourg: Publications Office of the European Union.

Evertsson M, Grunow D and Aisenbrey S (2016) Work interruptions and young women's career prospects in Germany, Sweden and the US. Work, Employment and Society 30(2): 291-308.

Fasang AE (2012) Retirement patterns and income inequality. Social Forces 90(3): 685-711.

Fenton S and Dermott E (2006) Fragmented careers? Winners and losers in young adult labour markets. Work, Employment and Society 20(2): 205-221.

Frocrain P and Giraud P-N (2017) The Evolution of Tradable and Non-tradable Employment: Evidence from France. i3 Working Papers Series. Paris: The Interdisciplinary Institute of Innovation.

Gabadinho A, Ritschard G, Studer M and Müller N (2010) Mining sequence data in R with the TraMineR package: A user’s guide. University of Geneva.

Grönlund A, Halldén K and Magnusson C (2017) A Scandinavian success story? Women’s labour market outcomes in Denmark, Finland, Norway and Sweden. Acta Sociologica 60(2): 97-119.

Härkönen J and Bihagen E (2011) Occupational attainment and career progression in Sweden. European Societies 13(3): 451-479. 
Härkönen J, Manzoni A and Bihagen E (2016) Gender inequalities in occupational prestige across the working life: An analysis of the careers of West Germans and Swedes born from the 1920s to the 1970s. Advances in Life Course Research 29: 41-51.

Hollister M (2011) Employment stability in the U.S. labor market: Rhetoric versus reality. Annual Review of Sociology 37(1): 305-324.

Jann B (2008) The Blinder-Oaxaca decomposition for linear regression models. The Stata Journal 8(4): 453-479.

Jarvis BF and Song X (2017) Rising intragenerational occupational mobility in the United States, 1969 to 2011. American Sociological Review 82(3): 568-599.

Kalleberg A (2011) Good Jobs, Bad Jobs: The Rise of Polarized and Precarious Employment Systems in the United States, 1970s-2000s, New York: Russell Sage Foundation.

Kitagawa EM (1955) Components of a difference between two rates. Journal of the American Statistical Association 50(272): 1168-1194.

Kuitto K, Salonen J and Helmdag J (2019) Gender inequalities in early career trajectories and parental leaves: Evidence from a Nordic welfare state. Social Sciences 8(9): 253.

Lahtinen H, Sirniö O and Martikainen P (2020) Social class and the risk of unemployment: Trends, gender differences and the contribution of education. Acta Sociologica 63(3): 303-321.

López-Andreu M and Rubery J (2018) Austerity and women’s employment trajectories in Spain and the UK: A comparison of two flexible labour markets. Economic and Industrial Democracy. Epub ahead of print 22 March 2018. DOI: 10.1177/0143831X18760988.

Manzoni A, Härkönen J and Mayer KU (2014) Moving on? A growth-curve analysis of occupational attainment and career progression patterns in West Germany. Social Forces 92(4): 1285-1312.

Mayer KU (2005) Life courses and life chances in a comparative perspective. In: Svallfors S (ed) Analyzing Inequality: Life Chances and Social Mobility in Comparative Perspective. Stanford: Stanford University Press, pp. 17-55. 
Möhring K (2016) Life course regimes in Europe: Individual employment histories in comparative and historical perspective. Journal of European Social Policy 26(2): 124-139.

Oaxaca R (1973) Male-female wage differentials in urban labor markets. International Economic Review 14(3): 693-709.

Pelletier D, Bignami-Van Assche S and Simard-Gendron A (2020) Measuring life course complexity with dynamic sequence analysis. Social Indicators Research 152: 1127-1151.

Piton S (2018) Do unit labor costs matter? A decomposition exercise on European data. CEPII Working Papers. Paris: CEPII.

Potter J (2015) Crisis at Work: Identity and the End of Career. Basingstoke: Palgrave Macmillan. Pyöriä P (2006) Understanding Work in the Age of Information: Finland in Focus. Tampere: Tampere University Press.

Riekhoff A-J (2018) Extended working lives and late-career destabilisation: A longitudinal study of Finnish register data. Advances in Life Course Research 35: 114-125.

Ritschard G, Bussi M and O’Reilly J (2018) An index of precarity for measuring early employment insecurity. In: Ritschard G and Studer M (eds) Sequence Analysis and Related Approaches. Life Course Research and Social Policies. Cham: Springer, pp. 279-295.

Rokkanen M and Uusitalo R (2010) Changes in job stability: Evidence from lifetime job histories. IZA Discussion Paper. Bonn: IZA.

Rubery J, Keizer A and Grimshaw D (2016) Flexibility bites back: The multiple and hidden costs of flexible employment policies. Human Resource Management Journal 26(3): 235-251.

Schellenberg C, Krauss A, Hättich A and Häfeli K (2016) Occupational career patterns over 30 years: Predictors and outcomes. Empirical Research in Vocational Educational and Training 8(1): $1-22$. 
Scherer S (2005) Patterns of labour market entry - long wait or career instability? An empirical comparison of Italy, Great Britain and West Germany. European Sociological Review 21(5): 427-440.

Stawarz N (2018) Patterns of intragenerational social mobility: An analysis of heterogeneity of occupational careers. Advances in Life Course Research 38: 1-11.

Struffolino E and Raitano M (2020) Early-career complexity before and after labour-market deregulation in Italy: Heterogeneity by gender and socio-economic status across cohorts. Social Indicators Research 151: 231-257.

Van Winkle Z and Fasang A (2017) Complexity in employment life courses in Europe in the Twentieth Century - Large cross-national differences but little change across birth cohorts. Social Forces 96(1): 1-30.

Widmer ED and Ritschard G (2009) The de-standardization of the life course: Are men and women equal? Advances in Life Course Research 14: 28-39.

Virtanen P, Lipiäinen L, Hammarström A, Janlert U, Saloniemi A and Nummi T (2011) Tracks of labour market attachment in early middle age: A trajectory analysis over 12 years. Advances in Life Course Research 16: 55-64. 


\section{Figures}

Figure 1. Employment status at age 30 by birth year, percentage of the study population.

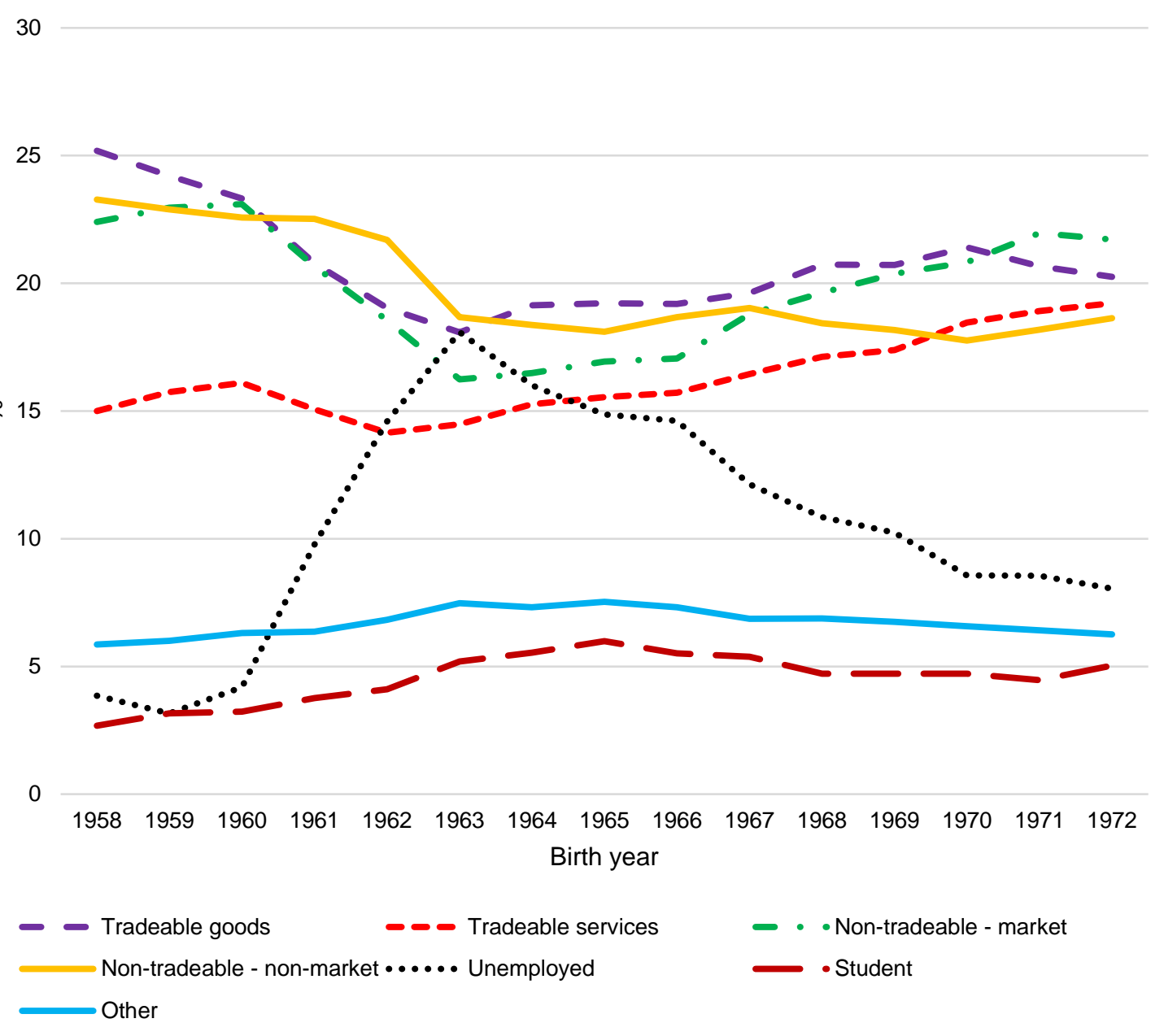


Figure 2. Career turbulence by cohort and gender: a) Status turbulence and b) Status and job turbulence

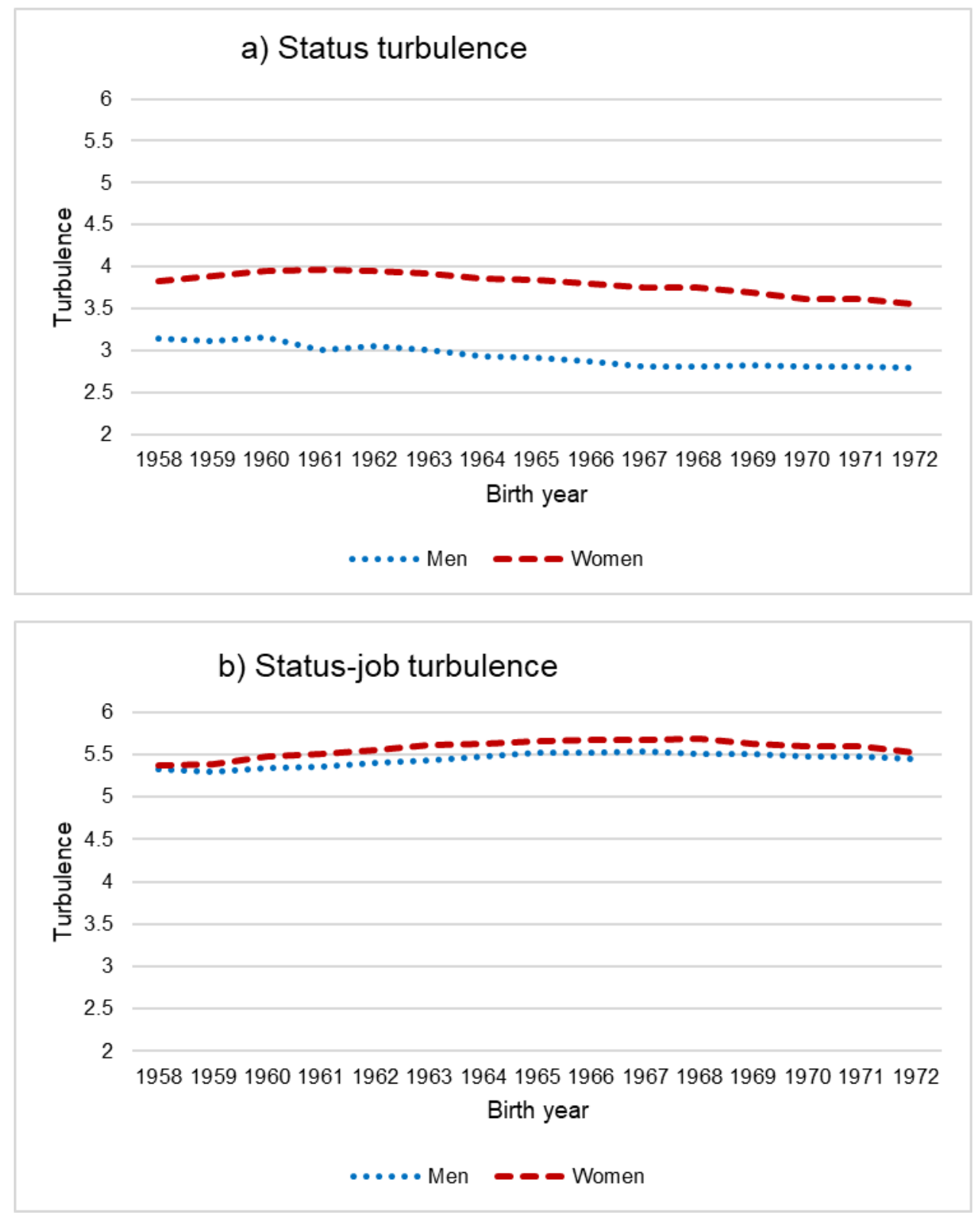


Figure 3. Decomposition of average changes in career turbulence between the 1958-1962 and 1963-1967 birth cohorts: a) Men, status turbulence, b) Women, status turbulence, c) Men, status-job turbulence, and d) Women, status-job turbulence

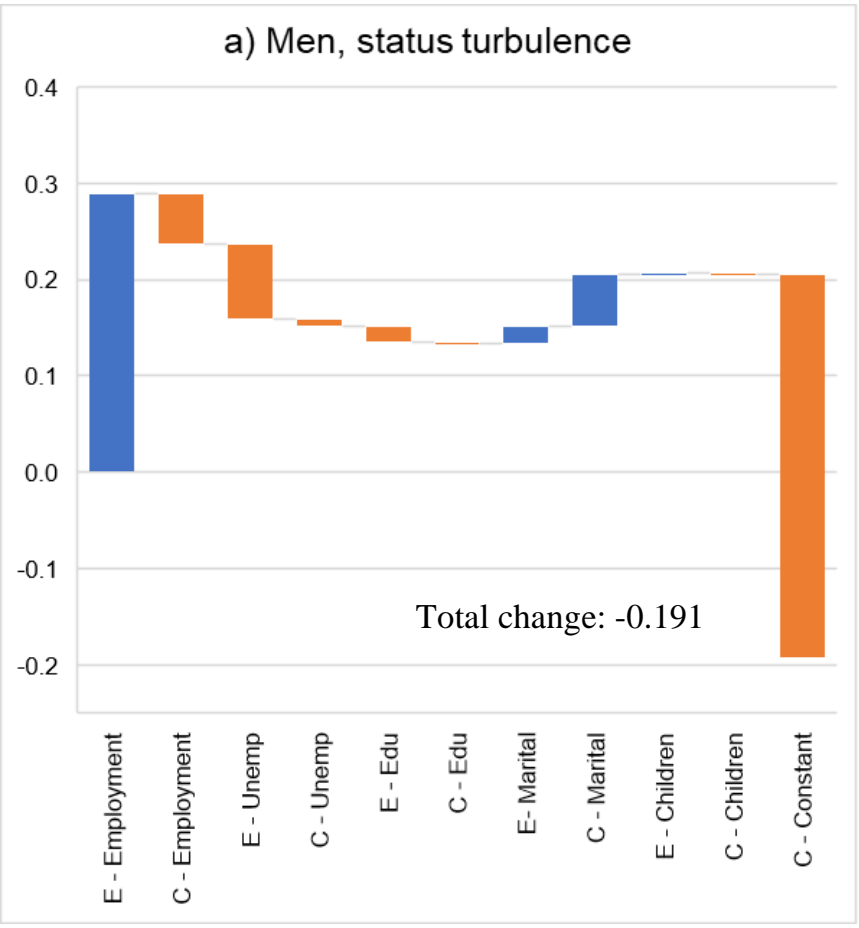

b) Women, status turbulence

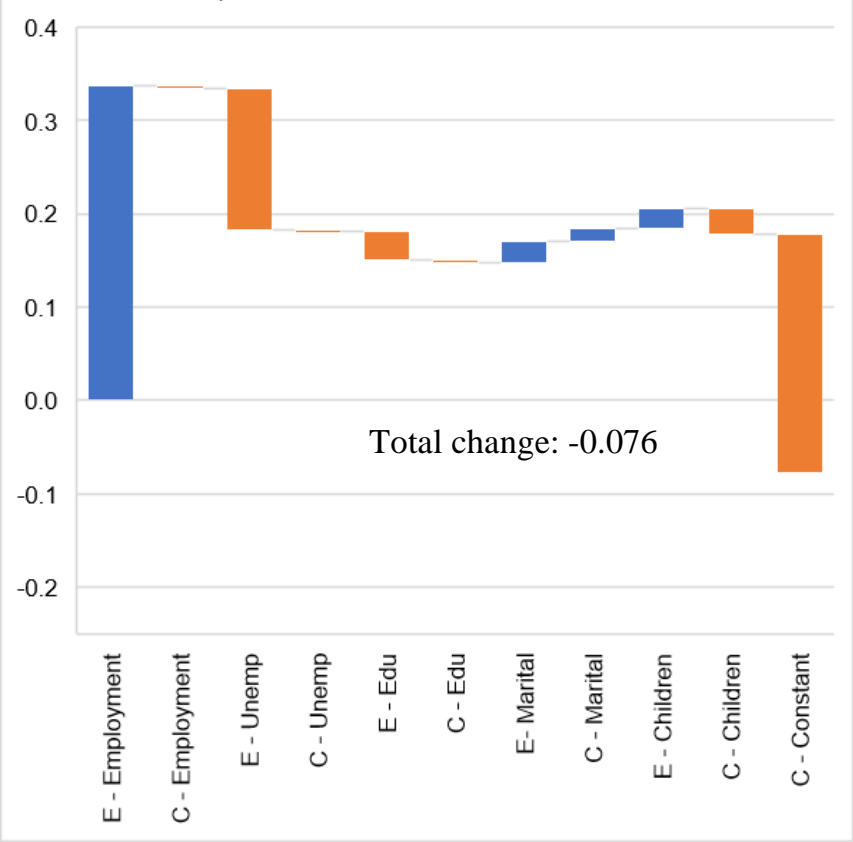



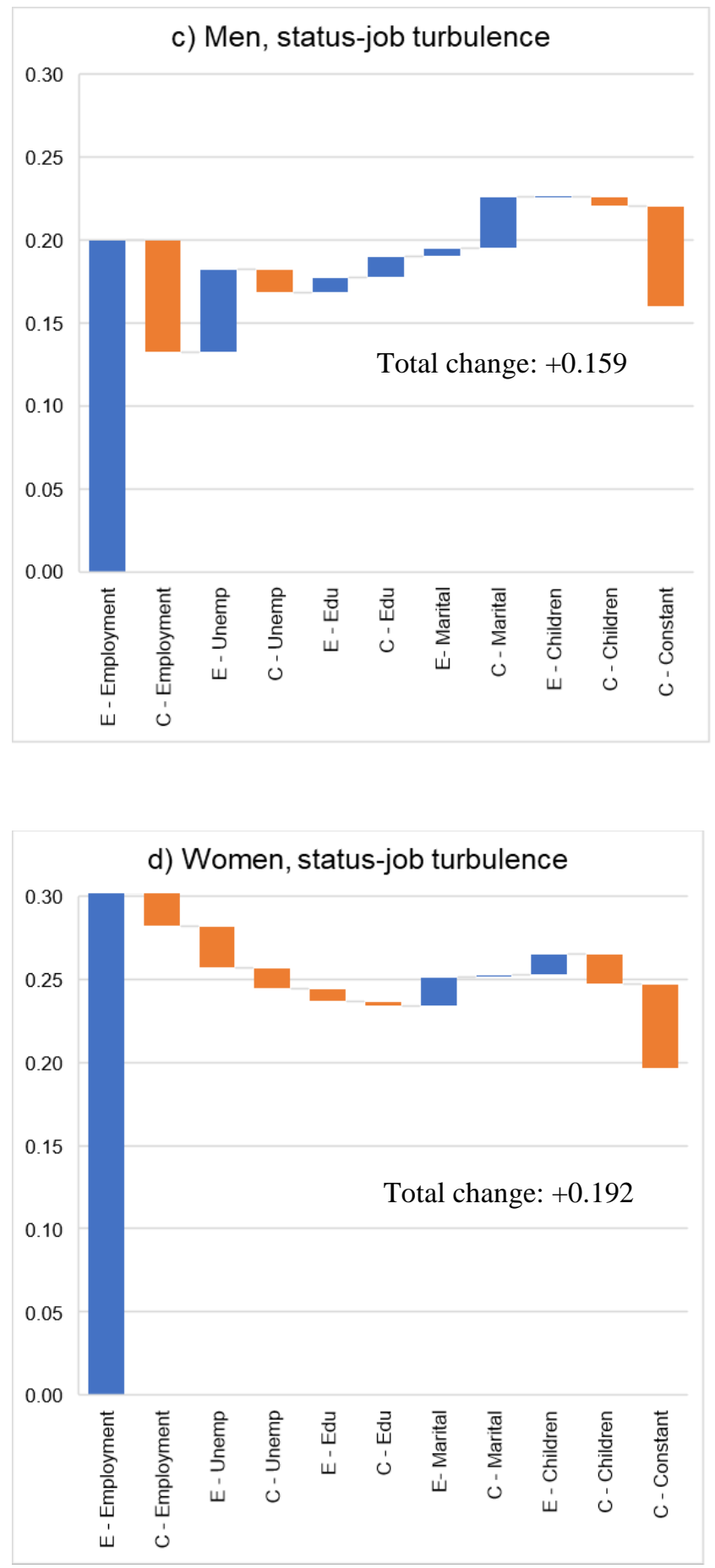

Note: $\mathrm{E}=$ Endowments, $\mathrm{C}=$ Coefficients, Employment $=$ Employment status at age 30, Unemp $=$ Regional unemployment rate, Edu = Level of education, Marital = Marital status 
Figure 4. Decomposition of average changes in career turbulence between the 1958-1962 and 1968-1972 birth cohorts: a) Men, status turbulence, b) Women, status turbulence, c) Men, status-job turbulence, and d) Women, status-job turbulence

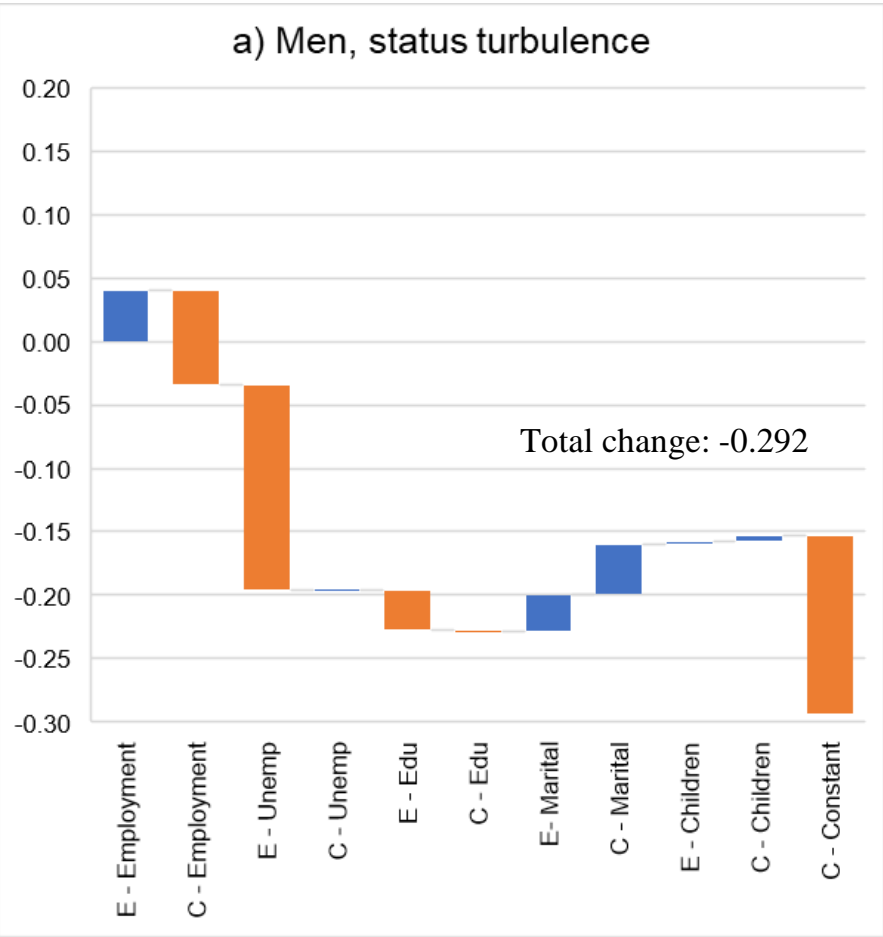

b) Women, status turbulence

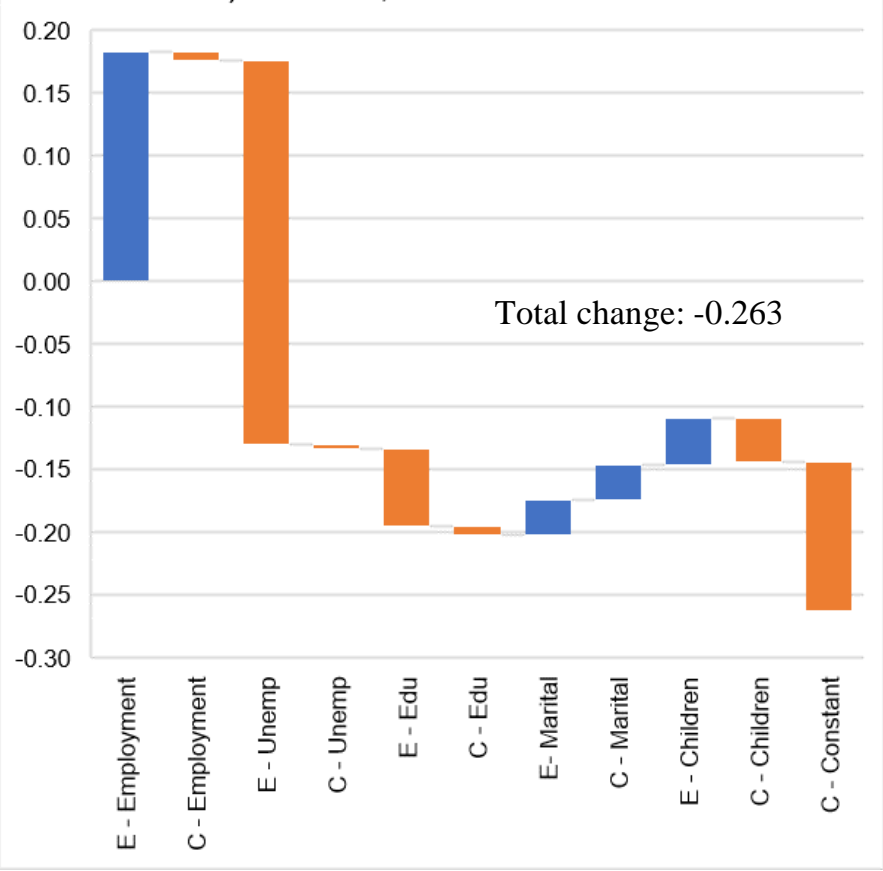




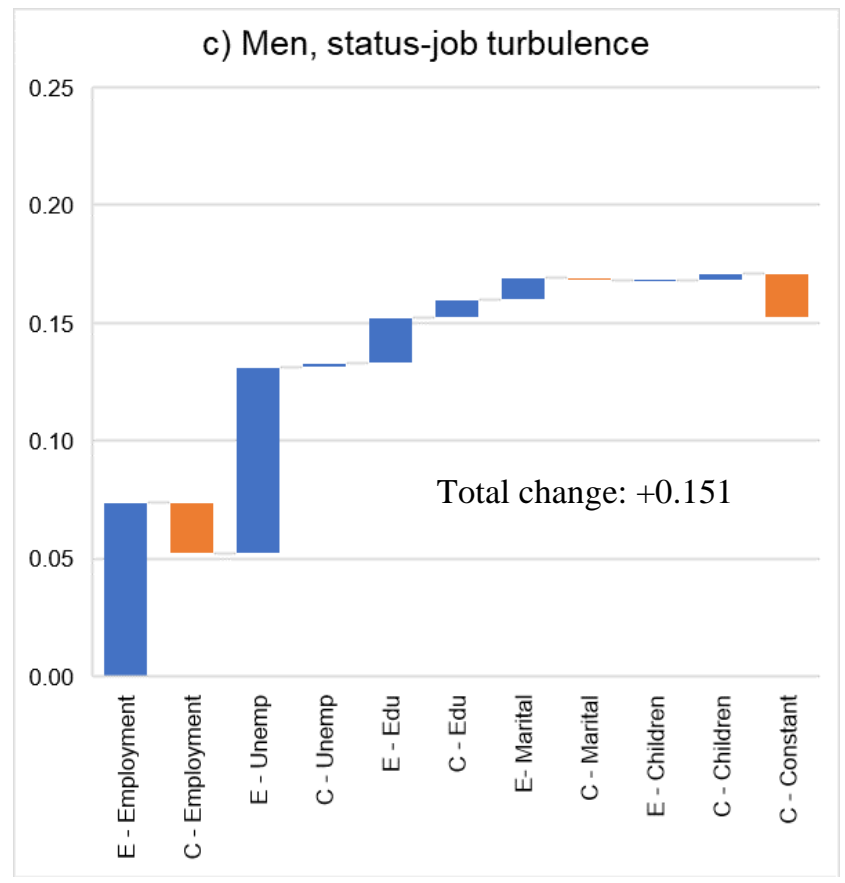

d) Women, status-job turbulence

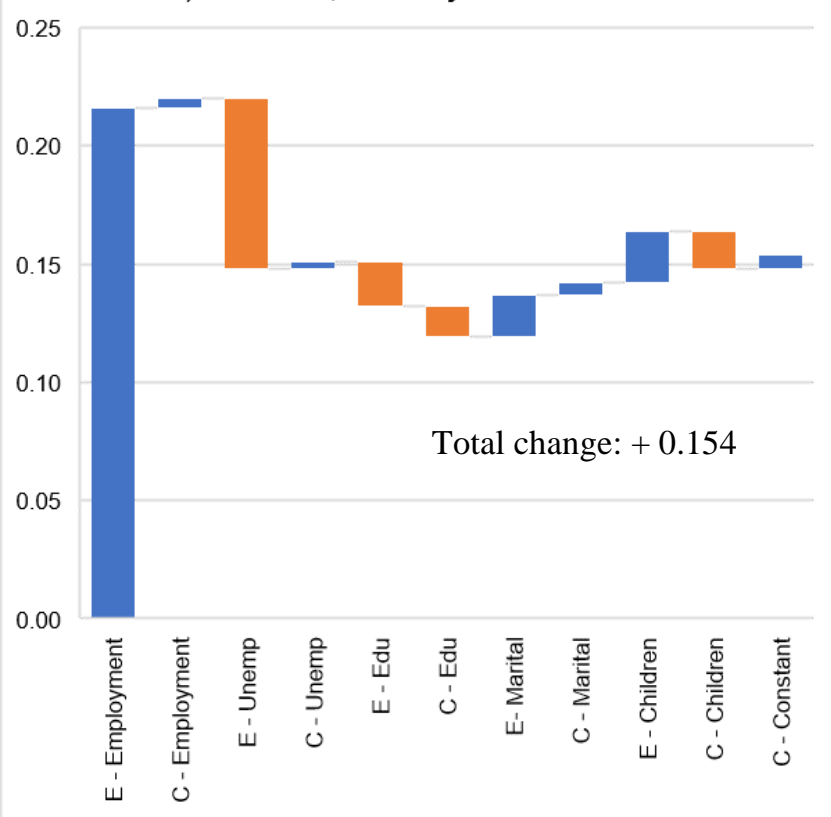

Note: $\mathrm{E}=$ Endowments, $\mathrm{C}=$ Coefficients, Employment $=$ Employment status at age 30, Unemp = Regional unemployment rate, Edu = Level of education, Marital = Marital status 


\section{Tables}

Table 1. Summary statistics.

\begin{tabular}{|c|c|c|}
\hline Variable & & Mean (SE) or \% \\
\hline \multicolumn{3}{|l|}{ Dependent variables } \\
\hline Status turbulence & & $3.37(2.70)$ \\
\hline Status-job turbulence & & $5.50(3.04)$ \\
\hline \multicolumn{3}{|l|}{ Independent variables } \\
\hline Women & & $49.13 \%$ \\
\hline Years in education & & $12.68(2.47)$ \\
\hline Regional unemployment rate & & $13.07(3.64)$ \\
\hline \multirow[t]{3}{*}{ Marital status at age 30} & Unmarried & $46.68 \%$ \\
\hline & Married & $48.29 \%$ \\
\hline & Divorced/widowed & $5.03 \%$ \\
\hline \multirow[t]{4}{*}{ Family formation } & No children & $24.84 \%$ \\
\hline & No children at 30, children at 44 & $22.44 \%$ \\
\hline & Children, same number at 30 and 44 & $37.62 \%$ \\
\hline & Children at 30, more at 44 & $15.10 \%$ \\
\hline \multirow[t]{8}{*}{ Employment status at age 30} & Tradeable goods sector & $20.78 \%$ \\
\hline & Tradeable services sector & $16.19 \%$ \\
\hline & Non-tradeable - market sector & $19.79 \%$ \\
\hline & Non-tradeable - non-market sector & $19.90 \%$ \\
\hline & Unemployed & $10.58 \%$ \\
\hline & Student & $4.53 \%$ \\
\hline & Other & $6.72 \%$ \\
\hline & Employed, sector unknown & $1.52 \%$ \\
\hline
\end{tabular}


Table 2. OLS regression results, predictors of career instability.

\begin{tabular}{|c|c|c|c|c|c|}
\hline & & $\begin{array}{c}1 . \\
\text { Men, status } \\
\text { turbulence }\end{array}$ & $\begin{array}{c}2 . \\
\text { Women, } \\
\text { status } \\
\text { turbulence }\end{array}$ & $\begin{array}{c}3 . \\
\text { Men, status- } \\
\text { job } \\
\text { turbulence }\end{array}$ & $\begin{array}{c}\text { 4. } \\
\text { Women, } \\
\text { status-job } \\
\text { turbulence }\end{array}$ \\
\hline \multirow{8}{*}{$\begin{array}{l}\text { Employment status at age } \\
30 \text { (ref. Employed in } \\
\text { tradeable goods sector) }\end{array}$} & Tradeable services & $0.060^{* * *}$ & $0.103^{* * *}$ & $0.403^{* * *}$ & $0.343 * * *$ \\
\hline & & $(0.009)$ & $(0.013)$ & $(0.012)$ & $(0.015)$ \\
\hline & $\begin{array}{l}\text { Non-tradeable } \\
\text { market }\end{array}$ & $\begin{array}{l}0.432 * * * \\
(0.009)\end{array}$ & $\begin{array}{l}0.147 * * * \\
(0.013)\end{array}$ & $\begin{array}{l}0.883^{* * *} \\
(0.011)\end{array}$ & $\begin{array}{l}0.322^{* * *} \\
(0.015)\end{array}$ \\
\hline & $\begin{array}{l}\text { Non-tradeable non- } \\
\text { market }\end{array}$ & $\begin{array}{l}-0.153^{* * *} \\
(0.010)\end{array}$ & $\begin{array}{l}-0.266 * * * \\
(0.012)\end{array}$ & $\begin{array}{l}-1.809 * * * \\
(0.013)\end{array}$ & $\begin{array}{l}-1.927 * * * \\
(0.014)\end{array}$ \\
\hline & Unemployed & $\begin{array}{l}3.141^{* * *} \\
(0.011)\end{array}$ & $\begin{array}{l}2.775^{* * *} \\
(0.015)\end{array}$ & $\begin{array}{l}2.186^{* * *} \\
(0.014)\end{array}$ & $\begin{array}{l}1.646^{* * *} \\
(0.017)\end{array}$ \\
\hline & Student & $\begin{array}{l}2.699 * * * \\
(0.017)\end{array}$ & $\begin{array}{l}2.283^{* * *} \\
(0.018)\end{array}$ & $\begin{array}{l}1.730 * * * \\
(0.022)\end{array}$ & $\begin{array}{l}1.118^{* * *} \\
(0.020)\end{array}$ \\
\hline & Other & $\begin{array}{l}3.080^{* * *} \\
(0.022)\end{array}$ & $\begin{array}{l}2.384^{* * *} \\
(0.014)\end{array}$ & $\begin{array}{l}2.143^{* * *} \\
(0.028)\end{array}$ & $\begin{array}{l}1.129 * * * \\
(0.016)\end{array}$ \\
\hline & Unknown & $\begin{array}{l}1.219 * * * \\
(0.024)\end{array}$ & $\begin{array}{l}0.965^{* * *} \\
(0.033)\end{array}$ & $\begin{array}{l}1.575^{* * *} \\
(0.030)\end{array}$ & $\begin{array}{l}0.952 * * * \\
(0.037)\end{array}$ \\
\hline $\begin{array}{l}\text { Regional unemployment } \\
\text { rate }\end{array}$ & & $\begin{array}{l}0.046^{* * *} \\
(0.001)\end{array}$ & $\begin{array}{l}0.084^{* * *} \\
(0.001)\end{array}$ & $\begin{array}{l}-0.023^{* * *} \\
(0.001)\end{array}$ & $\begin{array}{l}0.016^{* * *} \\
(0.001)\end{array}$ \\
\hline Years in education & & $\begin{array}{l}-0.066 * * * \\
(0.001)\end{array}$ & $\begin{array}{l}-0.096 * * * \\
(0.002)\end{array}$ & $\begin{array}{l}0.033^{* * *} \\
(0.002)\end{array}$ & $\begin{array}{l}-0.028 * * * \\
(0.002)\end{array}$ \\
\hline \multirow[t]{2}{*}{$\begin{array}{l}\text { Marital status at age } 30 \\
\text { (ref. Single) }\end{array}$} & Married & $\begin{array}{l}-0.242 * * * \\
(0.008)\end{array}$ & $\begin{array}{l}-0.248^{* * *} \\
(0.009)\end{array}$ & $\begin{array}{l}-0.072 * * * \\
(0.010)\end{array}$ & $\begin{array}{l}-0.172^{* * *} \\
(0.010)\end{array}$ \\
\hline & Divorced/widowed & $\begin{array}{l}0.433^{* * *} \\
(0.016)\end{array}$ & $\begin{array}{l}0.487^{* * *} \\
(0.015)\end{array}$ & $\begin{array}{l}0.574^{* * *} \\
(0.021)\end{array}$ & $\begin{array}{l}0.591^{* * *} \\
(0.018)\end{array}$ \\
\hline \multirow[t]{3}{*}{$\begin{array}{l}\text { Children (ref. No } \\
\text { children) }\end{array}$} & $\begin{array}{l}\text { Childless at } 30 \text {, } \\
\text { children at } 44\end{array}$ & $\begin{array}{l}-0.682 * * * \\
(0.008)\end{array}$ & $\begin{array}{l}0.817^{* * *} \\
(0.012)\end{array}$ & $\begin{array}{l}-0.163^{* * *} \\
(0.011)\end{array}$ & $\begin{array}{l}0.709^{* * *} \\
(0.013)\end{array}$ \\
\hline & $\begin{array}{l}\text { Children at } 30 \text {, no } \\
\text { change by } 44\end{array}$ & $\begin{array}{l}-0.454^{* * *} \\
(0.009)\end{array}$ & $\begin{array}{l}0.132 * * * \\
(0.011)\end{array}$ & $\begin{array}{l}-0.095^{* * *} \\
(0.012)\end{array}$ & $\begin{array}{l}0.222^{* * *} \\
(0.013)\end{array}$ \\
\hline & $\begin{array}{l}\text { Children at } 30 \text {, more } \\
\text { by } 44\end{array}$ & $\begin{array}{l}-0.777 * * * \\
(0.011)\end{array}$ & $\begin{array}{l}0.661^{* * *} \\
(0.013)\end{array}$ & $\begin{array}{l}-0.312 * * * \\
(0.014)\end{array}$ & $\begin{array}{l}0.525^{* * *} \\
(0.015)\end{array}$ \\
\hline Intercept & & $\begin{array}{l}3.212^{* * *} \\
(0.014)\end{array}$ & $\begin{array}{l}3.188^{* * *} \\
(0.018)\end{array}$ & $\begin{array}{l}5.262^{* * *} \\
(0.017)\end{array}$ & $\begin{array}{l}5.413^{* * *} \\
(0.020)\end{array}$ \\
\hline $\begin{array}{l}\text { Adj. R-squared empty } \\
\text { model with cohort } \\
\text { dummies only }\end{array}$ & & 0.003 & 0.002 & 0.001 & 0.001 \\
\hline Adj. R-squared full model & & 0.253 & 0.203 & 0.140 & 0.171 \\
\hline $\mathrm{N}$ & & 519,048 & 501,226 & 519,048 & 501,226 \\
\hline
\end{tabular}

Note: Cohort dummies included but not reported. ${ }^{*} \mathrm{p}<0.05$, ${ }^{* *} \mathrm{p}<0.01,{ }^{* * *} \mathrm{p}<0.001$ 


\section{Appendix}

Table A1. Bivariate results, OLS regression coefficients

\begin{tabular}{|c|c|c|c|}
\hline & & $\begin{array}{c}\text { Status } \\
\text { turbulence }\end{array}$ & $\begin{array}{l}\text { Status-job } \\
\text { turbulence }\end{array}$ \\
\hline Gender (ref. Male) & Female & $\begin{array}{l}0.858 * * * \\
(0.005)\end{array}$ & $\begin{array}{l}0.133 * * * \\
(0.006)\end{array}$ \\
\hline \multirow[t]{7}{*}{$\begin{array}{l}\text { Employment status at age } 30 \text { (ref. Employed in } \\
\text { tradeable goods sector) }\end{array}$} & Tradeable services & $\begin{array}{l}0.107^{* * *} \\
(0.008)\end{array}$ & $\begin{array}{l}0.498^{* * *} \\
(0.009)\end{array}$ \\
\hline & Non-tradeable market & $\begin{array}{l}0.383^{* * *} \\
(0.008)\end{array}$ & $\begin{array}{l}0.740^{* * *} \\
(0.009)\end{array}$ \\
\hline & Non-tradeable non-market & $\begin{array}{c}0.013 \\
(0.008)\end{array}$ & $\begin{array}{l}-1.642^{* * *} \\
(0.009)\end{array}$ \\
\hline & Unemployed & $\begin{array}{l}3.156^{* * *} \\
(0.009)\end{array}$ & $\begin{array}{l}2.034^{* * *} \\
(0.011)\end{array}$ \\
\hline & Student & $\begin{array}{l}2.546^{* * * *} \\
(0.012)\end{array}$ & $\begin{array}{l}1.563^{* * * *} \\
(0.014)\end{array}$ \\
\hline & Other & $\begin{array}{l}2.901^{* * *} \\
(0.011)\end{array}$ & $\begin{array}{l}1.603^{* * *} \\
(0.012)\end{array}$ \\
\hline & Unknown & $\begin{array}{l}1.198^{* * *} \\
(0.020)\end{array}$ & $\begin{array}{l}1.388^{* * *} \\
(0.023)\end{array}$ \\
\hline \multicolumn{2}{|l|}{ Regional unemployment rate } & $\begin{array}{l}0.083^{* * *} \\
(0.001)\end{array}$ & $\begin{array}{l}-0.010^{* * *} \\
(0.001)\end{array}$ \\
\hline \multicolumn{2}{|l|}{ Years in education } & $\begin{array}{l}-0.120 * * * \\
(0.001)\end{array}$ & $\begin{array}{l}-0.081^{* * *} \\
(0.001)\end{array}$ \\
\hline \multirow[t]{2}{*}{ Marital status at age 30 (ref. Single) } & Married & $\begin{array}{l}-0.289 * * * \\
(0.005)\end{array}$ & $\begin{array}{l}-0.224^{* * *} \\
(0.006)\end{array}$ \\
\hline & Divorced/widowed & $\begin{array}{l}0.810^{* * *} \\
(0.012)\end{array}$ & $\begin{array}{l}0.765^{* * *} \\
(0.014)\end{array}$ \\
\hline Children (ref. No children) & $\begin{array}{l}\text { Childless at } 30, \text { children at } \\
44 \\
\text { Children at } 30, \text { no change } \\
\text { by } 44 \\
\text { Children at } 30, \text { more by } 44\end{array}$ & $\begin{array}{l}-0.447^{* * *} \\
(0.008) \\
-0.135^{* * *} \\
(0.007) \\
-0.376^{* * *} \\
(0.009) \\
\end{array}$ & $\begin{array}{l}-0.041^{* * *} \\
(0.009) \\
-0.046^{* * *} \\
(0.008) \\
-0.183^{* * *} \\
(0.010) \\
\end{array}$ \\
\hline \multirow[t]{13}{*}{ Birth year (ref. 1958) } & 1959 & $\begin{array}{c}0.009 \\
(0.014)\end{array}$ & $\begin{array}{l}-0.004 \\
(0.016)\end{array}$ \\
\hline & 1960 & $\begin{array}{l}0.061^{* * *} \\
(0.014)\end{array}$ & $\begin{array}{l}0.068^{* * * *} \\
(0.016)\end{array}$ \\
\hline & 1961 & $\begin{array}{l}0.043 * * \\
(0.014)\end{array}$ & $\begin{array}{l}0.090^{* * *} \\
(0.016)\end{array}$ \\
\hline & 1962 & $\begin{array}{c}0.012 \\
(0.014)\end{array}$ & $\begin{array}{l}0.131^{* * *} \\
(0.016)\end{array}$ \\
\hline & 1963 & $\begin{array}{l}-0.027 \\
(0.014)\end{array}$ & $\begin{array}{l}0.180^{* * * *} \\
(0.016)\end{array}$ \\
\hline & 1964 & $\begin{array}{l}-0.098^{* * * *} \\
(0.014)\end{array}$ & $\begin{array}{l}0.210^{* * * *} \\
(0.016)\end{array}$ \\
\hline & 1965 & $\begin{array}{l}-0.118^{* * * *} \\
(0.014)\end{array}$ & $\begin{array}{l}0.241 * * * \\
(0.016)\end{array}$ \\
\hline & 1966 & $\begin{array}{l}-0.158 * * * \\
(0.014)\end{array}$ & $\begin{array}{l}0.256^{* * *} \\
(0.016)\end{array}$ \\
\hline & 1967 & $\begin{array}{l}-0.212^{* * *} \\
(0.014)\end{array}$ & $\begin{array}{l}0.261^{* * *} \\
(0.016)\end{array}$ \\
\hline & 1968 & $\begin{array}{l}-0.217^{* * * *} \\
(0.015)\end{array}$ & $\begin{array}{l}0.251^{* * * *} \\
(0.016)\end{array}$ \\
\hline & 1969 & $\begin{array}{l}-0.242^{* * * *} \\
(0.015)\end{array}$ & $\begin{array}{l}0.222^{* * * *} \\
(0.017)\end{array}$ \\
\hline & 1970 & $\begin{array}{l}-0.280^{* * *} \\
(0.015)\end{array}$ & $\begin{array}{l}0.191^{* * *} \\
(0.017)\end{array}$ \\
\hline & 1971 & $-0.278 * * *$ & $0.188 * * *$ \\
\hline
\end{tabular}




\begin{tabular}{|c|c|c|c|}
\hline & 1972 & $\begin{array}{l}(0.015) \\
-0.320^{* * *} \\
(0.015)\end{array}$ & $\begin{array}{c}(0.017) \\
0.142^{* * *} \\
(0.017)\end{array}$ \\
\hline $\mathrm{N}$ & & \multicolumn{2}{|c|}{$1,020,274$} \\
\hline
\end{tabular}

Note: ${ }^{*} \mathrm{p}<0.05,{ }^{* *} \mathrm{p}<0.01,{ }^{* * *} \mathrm{p}<0.001$ 
Table A2. Detailed decomposition of changes in career turbulence

\begin{tabular}{|c|c|c|c|c|c|c|c|c|}
\hline & \multicolumn{4}{|c|}{ Status turbulence } & \multicolumn{4}{|c|}{ Status-job turbulence } \\
\hline & \multicolumn{2}{|c|}{ Men } & \multicolumn{2}{|c|}{ Women } & \multicolumn{2}{|c|}{ Men } & \multicolumn{2}{|c|}{ Women } \\
\hline & $\begin{array}{c}1958-1962- \\
1963-1967 \\
\end{array}$ & $\begin{array}{c}1958-1962- \\
1968-1972 \\
\end{array}$ & $\begin{array}{c}1958-1962- \\
1963-1967 \\
\end{array}$ & $\begin{array}{c}1958-1962- \\
1968-1972 \\
\end{array}$ & $\begin{array}{c}1958-1962- \\
1963-1967 \\
\end{array}$ & $\begin{array}{c}1958-1962- \\
1968-1972 \\
\end{array}$ & $\begin{array}{c}1958-1962- \\
1963-1967 \\
\end{array}$ & $\begin{array}{c}1958-1962- \\
1968-1972 \\
\end{array}$ \\
\hline Difference & $\begin{array}{l}0.191^{* * *} \\
(0.009)\end{array}$ & $\begin{array}{l}0.292 * * * \\
(0.009)\end{array}$ & $\begin{array}{l}0.076^{* * *} \\
(0.009)\end{array}$ & $\begin{array}{l}0.263 * * * \\
(0.010)\end{array}$ & $\begin{array}{l}-0.159 * * * \\
(0.010)\end{array}$ & $\begin{array}{l}-0.151^{* * *} \\
(0.010)\end{array}$ & $\begin{array}{l}-0.192^{* * *} \\
(0.010)\end{array}$ & $\begin{array}{l}-0.154 * * * \\
(0.011)\end{array}$ \\
\hline Endowments & $\begin{array}{l}-0.214^{* * *} \\
(0.005)\end{array}$ & $\begin{array}{l}0.120^{* * *} \\
(0.006)\end{array}$ & $\begin{array}{l}-0.197 * * * \\
(0.005)\end{array}$ & $\begin{array}{l}0.121^{* * *} \\
(0.007)\end{array}$ & $\begin{array}{l}-0.264^{* * *} \\
(0.005)\end{array}$ & $\begin{array}{l}-0.181^{* * *} \\
(0.007)\end{array}$ & $\begin{array}{l}-0.298^{* * *} \\
(0.006)\end{array}$ & $\begin{array}{l}-0.165^{* * *} \\
(0.008)\end{array}$ \\
\hline Coefficients & $\begin{array}{l}0.406^{* * *} \\
(0.007)\end{array}$ & $\begin{array}{l}0.172^{* * *} \\
(0.009)\end{array}$ & $\begin{array}{l}0.272^{* * *} \\
(0.009)\end{array}$ & $\begin{array}{l}0.142^{* * *} \\
(0.010)\end{array}$ & $\begin{array}{l}0.105^{* * *} \\
(0.010)\end{array}$ & $\begin{array}{l}0.030^{* *} \\
(0.011)\end{array}$ & $\begin{array}{l}0.106^{* * *} \\
(0.010)\end{array}$ & $\begin{array}{c}0.011 \\
(0.012)\end{array}$ \\
\hline $\begin{array}{l}\text { Per cent explained } \\
\text { Detailed } \\
\text { endowments }\end{array}$ & -112.0 & 41.4 & -295.2 & 46.0 & 166.0 & 119.9 & 155.2 & 107.1 \\
\hline Employment status & $\begin{array}{l}-0.289 * * * \\
(0.004)\end{array}$ & $\begin{array}{l}-0.041^{* * *} \\
(0.004)\end{array}$ & $\begin{array}{l}-0.338^{* * *} \\
(0.004)\end{array}$ & $\begin{array}{l}-0.182 * * * \\
(0.004)\end{array}$ & $\begin{array}{l}-0.200^{* * *} \\
(0.004)\end{array}$ & $\begin{array}{l}-0.074 * * * \\
(0.004)\end{array}$ & $\begin{array}{l}-0.302 * * * \\
(0.005)\end{array}$ & $\begin{array}{l}-0.216^{* * *} \\
(0.004)\end{array}$ \\
\hline $\begin{array}{l}\text { Regional } \\
\text { unemployment rate }\end{array}$ & $\begin{array}{l}0.078^{* * *} \\
(0.002)\end{array}$ & $\begin{array}{l}0.162^{* * *} \\
(0.005)\end{array}$ & $\begin{array}{l}0.152^{* * *} \\
(0.003)\end{array}$ & $\begin{array}{l}0.306^{* * *} \\
(0.005)\end{array}$ & $\begin{array}{l}-0.050 * * * \\
(0.003)\end{array}$ & $\begin{array}{l}-0.079 * * * \\
(0.006)\end{array}$ & $\begin{array}{l}0.025^{* * *} \\
(0.003)\end{array}$ & $\begin{array}{l}0.072 * * * \\
(0.006)\end{array}$ \\
\hline Years in education & $\begin{array}{l}0.017^{* * *} \\
(0.001)\end{array}$ & $\begin{array}{l}0.031 * * * \\
(0.001)\end{array}$ & $\begin{array}{l}0.031 * * * \\
(0.001)\end{array}$ & $\begin{array}{l}0.062^{* * *} \\
(0.001)\end{array}$ & $\begin{array}{l}-0.009 * * * \\
(0.001)\end{array}$ & $\begin{array}{l}-0.019 * * * \\
(0.001)\end{array}$ & $\begin{array}{l}0.007^{* * *} \\
(0.001)\end{array}$ & $\begin{array}{l}0.019 * * * \\
(0.001)\end{array}$ \\
\hline Marital status & $\begin{array}{l}-0.018^{* * *} \\
(0.001)\end{array}$ & $\begin{array}{l}-0.030 * * * \\
(0.001)\end{array}$ & $\begin{array}{l}-0.022 * * * \\
(0.001)\end{array}$ & $\begin{array}{l}-0.028 * * * \\
(0.002)\end{array}$ & $\begin{array}{l}-0.005^{* * *} \\
(0.001)\end{array}$ & $\begin{array}{l}-0.009 * * * \\
(0.002)\end{array}$ & $\begin{array}{l}-0.017 * * * \\
(0.001)\end{array}$ & $\begin{array}{l}-0.018^{* * *} \\
(0.002)\end{array}$ \\
\hline Children & $\begin{array}{l}-0.001 \\
(0.001)\end{array}$ & $\begin{array}{l}-0.002 \\
(0.001)\end{array}$ & $\begin{array}{l}-0.020^{* * * *} \\
(0.001)\end{array}$ & $\begin{array}{l}-0.037 * * * \\
(0.001)\end{array}$ & $\begin{array}{c}0.000 \\
(0.001)\end{array}$ & $\begin{array}{c}0.000 \\
(0.001)\end{array}$ & $\begin{array}{l}-0.012^{* * *} \\
(0.001)\end{array}$ & $\begin{array}{l}-0.022^{* *} \\
(0.001)\end{array}$ \\
\hline $\begin{array}{l}\text { Detailed } \\
\text { coefficients }\end{array}$ & & & & & & & & \\
\hline Employment status & $\begin{array}{l}0.052 * * * \\
(0.007)\end{array}$ & $\begin{array}{l}0.073^{* * * *} \\
(0.010)\end{array}$ & $\begin{array}{c}0.004 \\
(0.004)\end{array}$ & $\begin{array}{c}0.007 \\
(0.004)\end{array}$ & $\begin{array}{l}0.068 * * * \\
(0.009)\end{array}$ & $\begin{array}{c}0.022 * \\
(0.010)\end{array}$ & $\begin{array}{l}0.020^{* * *} \\
(0.005)\end{array}$ & $\begin{array}{l}-0.004 \\
(0.005)\end{array}$ \\
\hline $\begin{array}{l}\text { Regional } \\
\text { unemployment rate }\end{array}$ & $\begin{array}{l}0.007^{* *} \\
(0.002)\end{array}$ & $\begin{array}{c}0.000 \\
(0.001)\end{array}$ & $\begin{array}{c}0.001 \\
(0.002)\end{array}$ & $\begin{array}{c}0.003 \\
(0.002)\end{array}$ & $\begin{array}{l}0.014^{* * *} \\
(0.002)\end{array}$ & $\begin{array}{l}-0.002 \\
(0.002)\end{array}$ & $\begin{array}{l}0.013^{* * *} \\
(0.002)\end{array}$ & $\begin{array}{l}-0.003 \\
(0.002)\end{array}$ \\
\hline Years in education & $\begin{array}{c}0.002 \\
(0.002)\end{array}$ & $\begin{array}{c}0.002 * \\
(0.001)\end{array}$ & $\begin{array}{l}0.002 * * \\
(0.001)\end{array}$ & $\begin{array}{l}0.007^{* * *} \\
(0.001)\end{array}$ & $\begin{array}{l}-0.013^{* * *} \\
(0.002)\end{array}$ & $\begin{array}{l}-0.008 * * * \\
(0.001)\end{array}$ & $\begin{array}{l}0.003^{* * *} \\
(0.001)\end{array}$ & $\begin{array}{l}0.013^{* * *} \\
(0.002)\end{array}$ \\
\hline Marital status & $\begin{array}{l}-0.055^{* * *} \\
(0.013)\end{array}$ & $\begin{array}{l}-0.039 * * \\
(0.014)\end{array}$ & $\begin{array}{l}-0.015 \\
(0.010)\end{array}$ & $\begin{array}{l}-0.028^{* * *} \\
(0.011)\end{array}$ & $\begin{array}{l}-0.031^{*} \\
(0.014)\end{array}$ & $\begin{array}{c}0.001 \\
(0.016)\end{array}$ & $\begin{array}{c}0.002 \\
(0.011)\end{array}$ & $\begin{array}{l}-0.005 \\
(0.012)\end{array}$ \\
\hline Children & $\begin{array}{c}0.002 \\
(0.002)\end{array}$ & $\begin{array}{l}-0.005^{*} \\
(0.002)\end{array}$ & $\begin{array}{l}0.027^{* * *} \\
(0.005)\end{array}$ & $\begin{array}{l}0.035^{* * *} \\
(0.004)\end{array}$ & $\begin{array}{c}0.006^{*} \\
(0.003)\end{array}$ & $\begin{array}{l}-0.003 \\
(0.003)\end{array}$ & $\begin{array}{l}0.018^{* * *} \\
(0.005)\end{array}$ & $\begin{array}{l}0.016^{* *} \\
(0.005)\end{array}$ \\
\hline Constant & $\begin{array}{l}0.398^{* * *} \\
(0.017)\end{array}$ & $\begin{array}{l}0.141^{* * * *} \\
(0.019)\end{array}$ & $\begin{array}{l}0.255^{* * *} \\
(0.015)\end{array}$ & $\begin{array}{l}0.118^{* * *} \\
(0.017)\end{array}$ & $\begin{array}{l}0.060 * * \\
(0.020)\end{array}$ & $\begin{array}{c}0.019 \\
(0.022)\end{array}$ & $\begin{array}{l}0.051 * * \\
(0.016)\end{array}$ & $\begin{array}{l}-0.006 \\
(0.018)\end{array}$ \\
\hline $\mathrm{N}$ & 357,118 & 333,482 & 347,409 & 323,048 & 357,118 & 333,482 & 347,409 & 323,048 \\
\hline
\end{tabular}

